\section{WAARACHTIGE ARCHITECTUUR}

OVER AUTHENTICITEIT EN HERBESTEMMING

FREEK SCHMIDT

Het woord authenticiteit is niet onproblematisch in de wereld van de architectuur en erfgoed, zo blijkt uit verschillende bijdragen in dit nummer. In het kader van herbestemming is het gebruik van de term zelfs vaak zo ingewikkeld dat het aanleiding geeft om alternatieven aan te dragen, of het juist geheel te negeren. In deze bijdrage wordt authenticiteit opgevat als historiciteit; de waarachtigheid en eigenheid van een historisch gegroeid gebouw en zijn omgeving, fysiek en als drager van culturele betekenis. De vraag is wat het begrip historiciteit kan betekenen bij herbestemming - een groeiende ontwerpopgave die steeds meer als afzonderlijke discipline wordt gezien. ${ }^{1}$ Als ergens behoefte bestaat aan een helder begrippenkader dan is het wel in deze ontwerppraktijk, waarin met name architecten zich in toenemende mate ook als historici presenteren. In de groeiende stroom publicaties over herbestemming is nauwelijks sprake van een duidelijk afgebakend onderzoeksobject, laat staan van een wetenschappelijke houding ten aanzien van de historische leefomgeving en de manier waarop men daarin als ontwerper opereert. Tegelijkertijd heeft dit vaak ingrijpende gevolgen voor de waarde en betekenis van gebouw, stad en cultuurlandschap. In de praktijk wordt vanuit de lezing van het gebouw als architectonisch object een nieuw ontwerpconcept of een 'interventie' uitgewerkt in een combinatie van conservering, restauratie, sloop en nieuwbouw, toegespitst op 'het nieuwe leven' van het gebouw. Maar krijgt de historiciteit van onze omgeving zo wel voldoende aandacht? Deze bijdrage is een pleidooi voor onafhankelijk breed architectuurhistorisch onderzoek voorafgaand aan herontwikkeling, ter bescherming van de historische waarde en culturele betekenis van gebouwen.

-1. De Nederlandsche Bank, Frederiksplein, Amsterdam, 19 december 1967. Dit gebouw, ontworpen in 1961 door architect Marius Duintjer, werd in 1991 uitgebreid met een ronde toren naar ontwerp van Jelle Abma (foto G.L.W. Oppenheim, Stadsarchief Amsterdam,

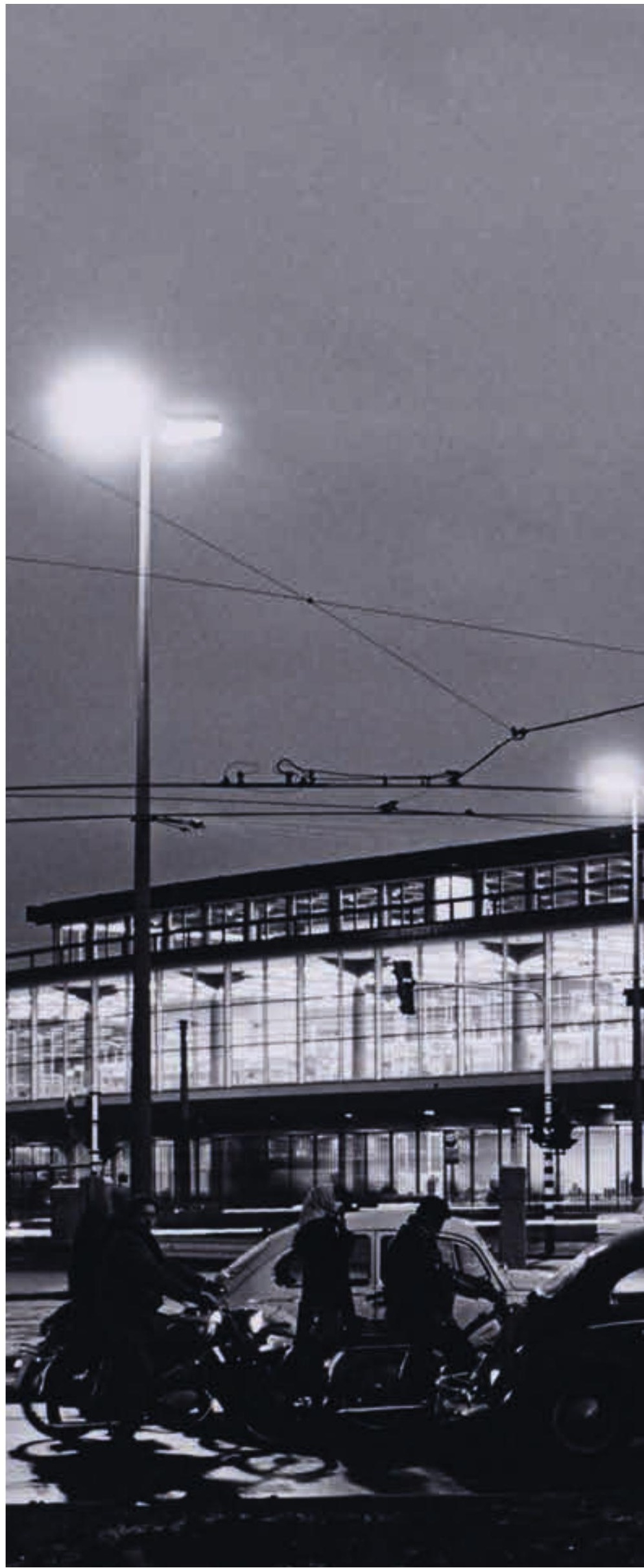
collectie Oppenheim) 


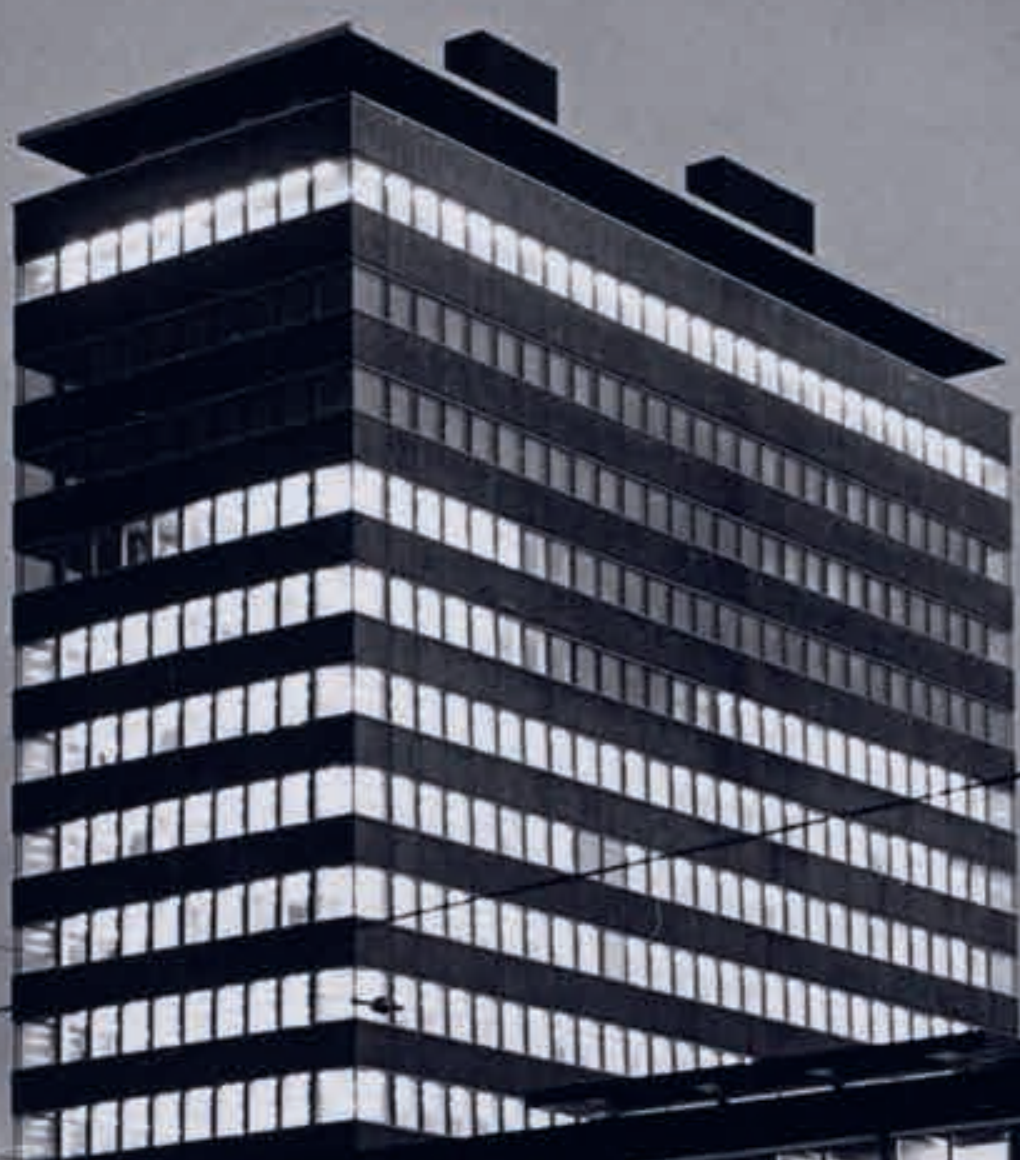

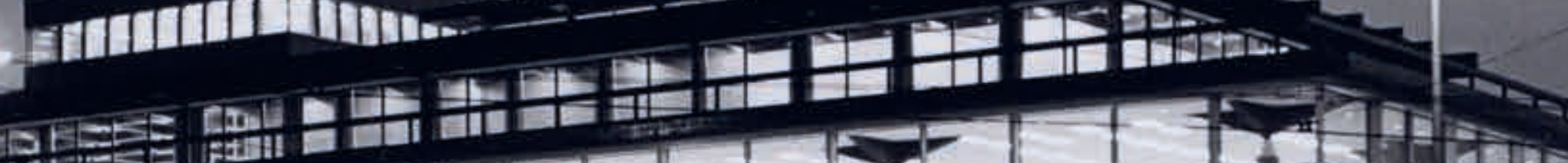
G.

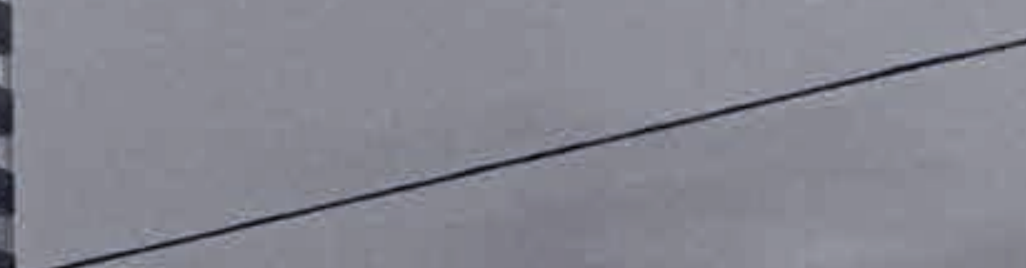

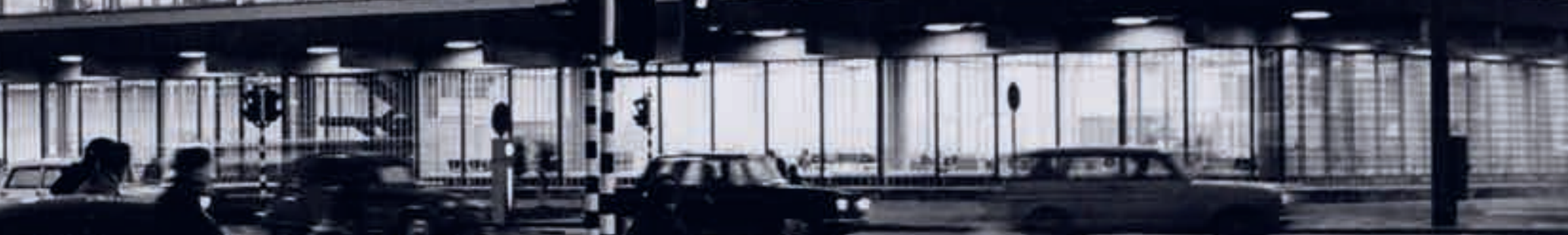

$$
\begin{aligned}
-3 & = \\
3 & -10
\end{aligned}
$$




\section{ALLE GEBOUWEN GROEIEN}

Vandaag de dag probeert de bouwwereld angstvallig om te gaan met de klimaatverandering, het tekort aan natuurlijke hulpbronnen en het ontwrichtende gedrag van de mens. Als gevolg hiervan wordt het idee dat gebouwen eenvoudig kunnen worden afgedankt steeds problematischer. Hoe kan architectuur veranderingen beter faciliteren en veerkrachtiger en duurzamer zijn? Het architectenvak en de erfgoedindustrie hebben de groeiende markt van herbestemming, 'adaptive reuse' in het Engels, van leegstaande en verouderde gebouwen omarmd. Hierbij worden nieuwe architectonische ontwerp- en conserveringstechnieken gecombineerd. Dit betekent een terugkeer naar premoderne praktijken, toen de architectonische cultuur werd gedomineerd door permanentie, duurzaamheid en geleidelijke verandering. ${ }^{2}$ Om te kunnen blijven functioneren moeten gebouwen meebewegen, synchroon blijven met de veranderingen om ze heen. Alle gebouwen groeien, stelde Stewart Brand vast in zijn aanstekelijke boek How buildings learn. What happens after they're built. $^{3}$ Een groot verschil echter met de premoderne praktijk schuilt in de benadering van het gebouwde. Doorgaans wordt in de recente literatuur over herbestemming - grotendeels voor en door architecten geschreven - impliciet onderscheid ge- maakt tussen het 'oorspronkelijke' gebouw en latere toevoegingen. Men heeft vaak meer ontzag voor het architectonische ontwerp dan voor de veranderingen die gebouwen ondergaan en die deel uitmaken van hun culturele geschiedenis en betekenis. ${ }^{4} \mathrm{Zo}$ is er relatief weinig aandacht voor gebruiksgeschiedenis, wanordelijke pragmatische aanpassingen en wat er in de loop der tijd aan gebouwen werd gedaan om ze te laten voortbestaan. ${ }^{5}$

Als een gebouw zijn functie heeft uitgediend, is het zelden waardeloos. De enige waarde die grotendeels is verdwenen, is financieel-economisch van aard. ${ }^{6}$ Het gebouw bezit waarde vanwege andere dan gebruikskwaliteiten, zoals de ruimtelijke waarde als stedenbouwkundig en architectonisch object. Vergeten wordt vaak de immateriële waarde die is verbonden met individuele en collectieve herinneringen, ontstaan door gebruik, speciale gebeurtenissen en getuigenissen in woord en beeld. Het Amsterdamse Paleis voor Volksvlijt kent bijna geen levend mens nog uit eigen ervaring. De populariteit van dit bouwwerk laat echter zien hoe groot die immateriële waarde op grond van documenten, getuigenissen en verhalen kan zijn. ${ }^{7}$ De historicus is als geen ander in staat om die waarde en betekenis van een gebouw op te sporen en te verklaren.

2. Frederiksplein, Amsterdam, restanten van het Paleis voor Volksvlijt (1864) na de brand, april 1929 (Stadsarchief Amsterdam)

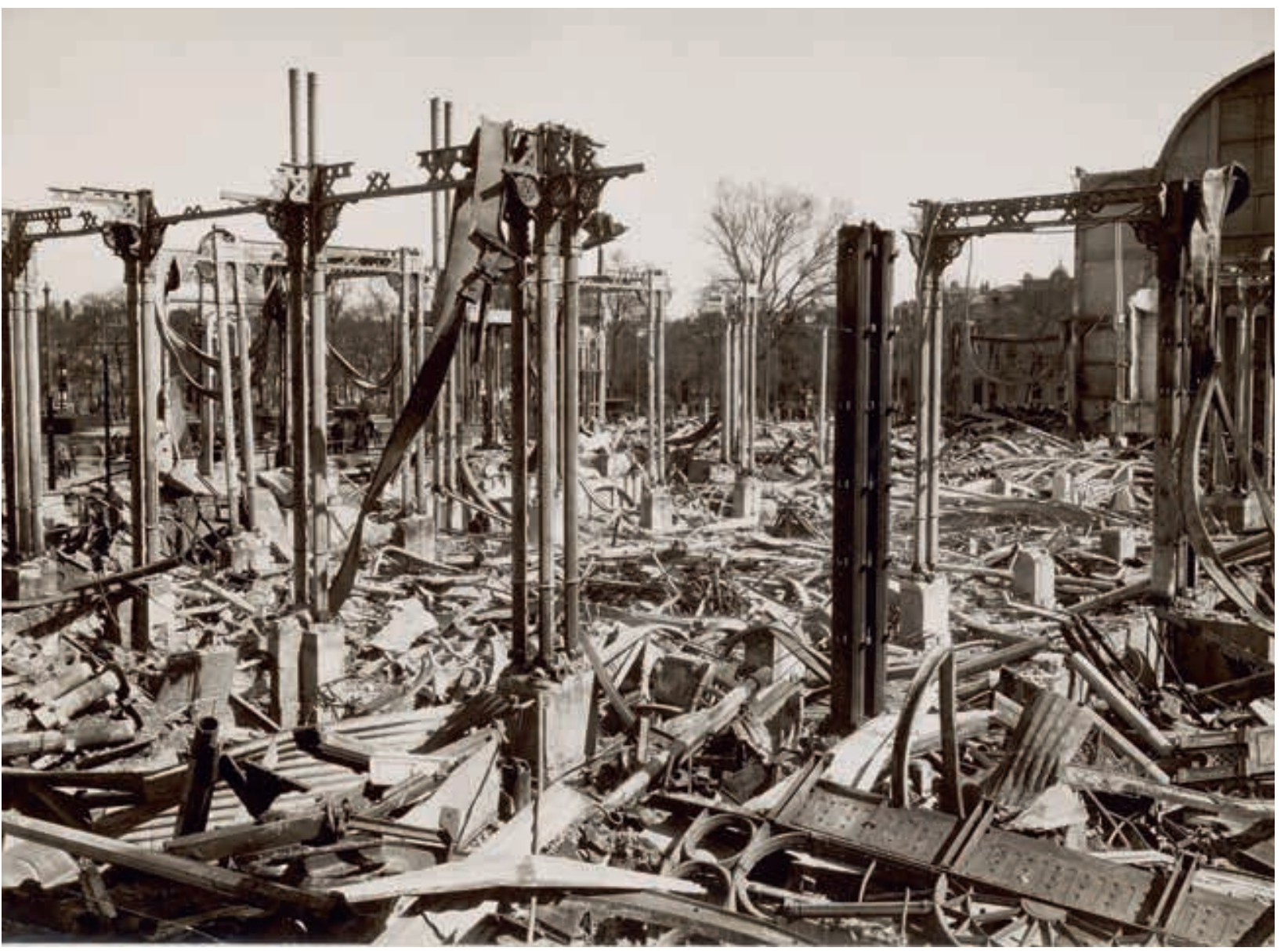




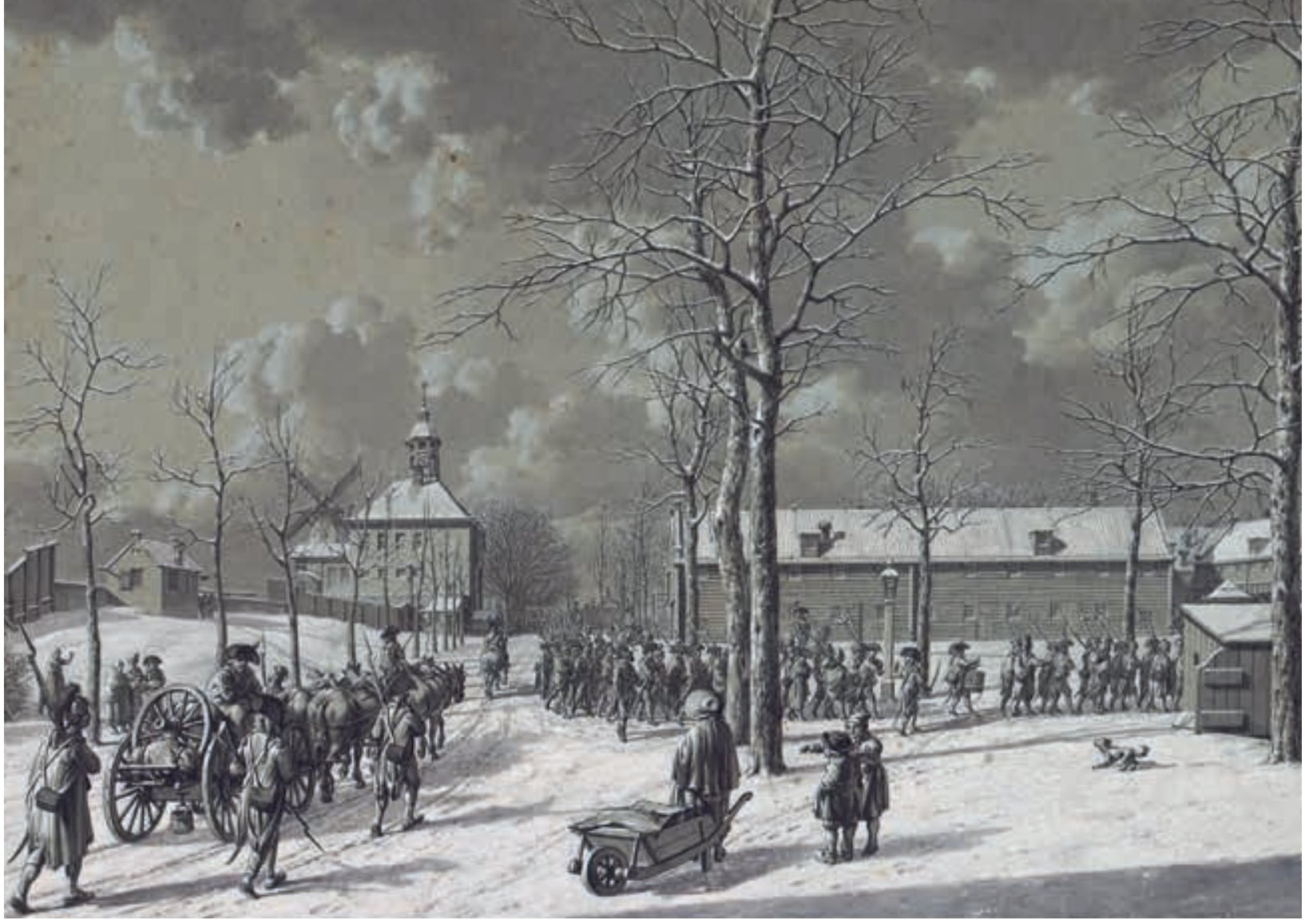

3. Jacob Cats, Het inrukken der Fransche Troupen in de Utregtsche Poort, 1796. Tekening van de intocht van de Franse soldaten op het (latere) Frederiksplein in de vroege ochtend van 19 januari 1795, gezien vanuit zijn huis aan het Amstelgrachtje. Links de Utrechtse Poort (1664-1858) (Stadsarchief Amsterdam)

\section{ERFGOEDMARKT}

Architectuurhistorici hebben de laatste decennia hun zorg uitgesproken over de fundamentele verandering die het monument ondergaat door, in de woorden van Hilde Heynen, 'the combined effects of tourism, commodification, the shifting place of the public realm and the transformations of the experience of time'. ${ }^{8}$ Toerisme en vermaak lijken steeds meer van invloed op de omgang met onze gebouwde omgeving. Musealisering is een van de problemen waarover binnen en buiten de erfgoedwereld levendig wordt gedebatteerd. Dit beperkt zich niet tot historische binnensteden en erkende monumenten. Historiciteit wordt overal ingeruild voor een vaag soort nostalgie die vooral aanzet tot consumptie en vermaak, waarbij behoud van historische fragmenten dient als alibi voor commerciële herontwikkeling en vastgoedtransacties. Geschiedenis wordt vervangen door entertainment. ${ }^{9}$ Bescherming en instandhouding gaan daarbij gepaard met verlies van werkelijke zorg en waardering voor de authentieke betekenis van het gebouwde erfgoed. ${ }^{10}$

In de internationale bouw- en erfgoedwereld kwam rond de eeuwwisseling 'adaptive reuse' op; in Nederland onder de slogan 'behoud door ontwikkeling' gestimuleerd door nieuw ruimtelijk beleid sinds de Nota Belvedere (1999). De groeiende koppeling van erfgoedwaarde aan economisch rendement wakkerde de belangstelling voor herbestemming verder aan. Zoals de beleidsvisie van het kabinet 'Kiezen voor karakter. Vi- sie erfgoed en ruimte' uit 2011 het formuleert: 'Zonder waardecreatie is er geen duurzame grondslag voor instandhouding en laten we bovendien kansen liggen om economisch profijt van dit "goud in onze handen" te vergroten.'11 Geheel in lijn daarmee is monumentenzorg omgevormd tot erfgoedmanagement en werd herbestemming een verdienmodel met een grote aantrekkingskracht op de bouwsector en projectontwikkelaars. Maar wat betekent dit voor de authenticiteit van onze gebouwde omgeving en hoe blijft historiciteit in deze, vooral door economie en vermaak gedreven dynamiek, overeind? Dat er bij de toevoeging van nieuwe waarden ook oude waarden, betekenis en historiciteit verdwijnen, krijgt tot op heden in de discussie rondom herbestemming nauwelijks aandacht.

\section{HET GEBOUW ALS ARTEFACT}

In recente publicaties over herbestemming vindt men meestal een combinatie van lippendienst aan de canon van de monumentenzorg, ontwerpopvattingen toegespitst op herontwikkeling en een persoonlijke selectie van praktijkvoorbeelden. ${ }^{12}$ Bestaande literatuur wordt fragmentarisch en willekeurig gebruikt, waardoor een stand van wetenschap ontbreekt. Opvallend is dat in het gros van de publicaties de studie van Brand vrijwel wordt genegeerd. ${ }^{13}$ Dat kan bewust zijn, want Brand stelt in de slotpagina's van zijn boek voor om architectuur niet langer te zien als de kunst van het bouwen, maar als " "the design-science of the life of 
buildings". A shift that minor could transform the way civilization manages its built environment - toward long-term responsibility and constant adaptivity. ${ }^{14}$ Kritisch-wetenschappelijke reflectie op de taak, positie en autoriteit van de architect binnen het erfgoeddiscours ontbreekt nagenoeg. Het bestaande gebouw wordt geanalyseerd als architectonisch artefact, als materieel restant, waarbij alle aandacht uitgaat naar het documenteren van de bouwhistorische substantie en het vaststellen van de zeldzaamheid en gaafheid van fysieke onderdelen. Zelden worden waarde en betekenis van het gebouw als cultuurhistorisch, soms generaties gekoesterd, doorleefd, gebruikt en aangepast object benoemd als uitgangspunt voor ingrijpen. Hierdoor ontbreekt de constatering dat bij een omvangrijk herontwerp het waarachtige van het gegroeide verdwijnt en daarmee zijn historiciteit. Dit roept de vraag op hoe veerkrachtig en duurzaam een herbestemming eigenlijk is of zou moeten zijn. Brand stelt: 'Almost no buildings adapt well. They're designed not to adapt, also budgeted and financed not to, constructed not to, administered not to, maintained not to, regulated and taxed not to, even remodeled not to. ${ }^{15}$ In plaats van de veerkracht van een gebouw te koesteren, gaat een te ingrijpende of grootschalige herontwikkeling ten koste van de belevingswaarde en collectieve herinnering die misschien wel onvervangbaar zijn. Wat de blijvende 'waardecreatie' hiervan zal zijn, is vooralsnog onbekend.

\section{DE 'GENIUS OF THE PLACE'}

Als alternatief voor het discutabele begrip authenticiteit grijpen Bie Plevoets en Koenraad Van Cleempoel in hun recente Adaptive reuse of the built heritage. Concepts and cases of an emerging discipline terug op 'the genius of the place'. ${ }^{16}$ In eerste instantie is deze term ontleend aan de achttiende-eeuwse Engelse dichter Alexander Pope, die hiermee duiding gaf aan de kwaliteiten van de Engelse landschapsarchitectuur waarin de aanwezige natuur tot groter genoegen van de mens werd herschikt naar de geest van de plek. Tegelijkertijd wordt ook verwezen naar de 'genius loci' die rond 1980 door architectuurhistoricus Christian NorbergSchulz werd betrokken op de architectuur. ${ }^{17}$ Herbestemming wordt hier beschouwd als 'an opportunity to recreate, rethink, or strengthen the genius loci'. ${ }^{18}$ Het gebouw wordt gezien als een plek waar de juxtapositie van verschillende historische lagen de authentieke ervaring, de rijkdom en diepte van de herinnering heeft vergroot. ${ }^{19}$ De auteurs stellen dat de nieuwe discipline van 'adaptive reuse' niet slechts het overgeleverde dient te respecteren, maar actief de waarde en herinnering van de 'gastruimte' moet opsporen en door een opeenvolging van tastbare en niet-tastbare associaties betekenisvolle relaties tussen heden en verleden moet bewerkstelligen..$^{20}$ Zo geformuleerd kan niemand hierop tegen zijn. Maar Pope's 'genius of the place' in het landschap is heel iets anders dan een oud gebouw of een doorleefde plek. We kunnen ons afvragen of het wel een goed idee is om degene die ontwerpt tevens de betekenis van een gebouw of plek te laten duiden. Een architectonisch geslaagde herbestemming kan immers een gevoelig verlies aan historiciteit en cultuurhistorische betekenis opleveren, terwijl de bouwhistorische substantie nagenoeg intact blijft.

Het is niet voldoende dat de architect à la Pope de 'genius of the place' van een bestaand gebouw en plek intuïtief en associatief leest en vertaalt in een zichtbare en ingrijpende transformatie, zonder dat de immateriële waarde en betekenis van gebouw en plek door een onafhankelijk (architectuur)historicus zijn geanalyseerd. Dit onderzoeken van de historische en culturele betekenis is in de discussie over herbestemming onderbelicht gebleven. In de huidige tijd, waarin steeds meer gebouwd erfgoed van jonge leeftijd op de schop gaat, zijn waarachtigheid en historiciteit van groot belang voor de invoelbaarheid en begrijpelijkheid van de gebouwde omgeving. Dit vraagt niet alleen om een bouwhistorische analyse, maar vooral om een beschrijving van de historische en gecumuleerde culturele waarde en betekenis van gebouw en plek als uitgangspunt voor herontwikkeling. Verhalen over het gebouw en de plek, intenties achter het ontwerp en gewijzigd gebruik, al die immateriële aspecten bepalen samen de culturele waarde van het gebouw in de samenleving. Die historiciteit, of waarachtigheid en eigenheid, heeft het gebouw nodig om betekenis te houden. Anders verdwijnt de geest van de plek en komen er slechts noviteit en vermaak voor in de plaats, gereed voor de hedendaagse consument.
NOTEN

1 Deze bijdrage borduurt voort op enkele ideeën die ontstonden in nauwe samenwerking met Marie-Thérèse van Thoor, Gabri van Tussenbroek, Ronald Stenvert, Jan van der Hoeve en Edwin Orsel ten behoeve van twee aanvragen voor programmatisch onderzoek bij Nwo van enkele jaren geleden (niet gehonoreerd), en op lopend onderzoek van de auteur naar de geschiedenis van aanpasbare architectuur. Literatuur geraadpleegd voor dit artikel: C. Bloszies, Old buildings, new designs. Architectural transformations, New York 2012; E. Braae, Beauty redeemed. Recycling postindustrial landscapes, Risskov/Bazel 2015; Crimson, Re-Arch. Nieuwe ontwerpen voor oude gebouwen, Rotterdam 1995; P. Diederen, Ontwerpen van verandering. Intreerede prof. ir. Paul Diederen. Uitgesproken op 1 juni 2018 aan de Technische Universiteit Eindhoven (https://research. tue.nl/nl/publications/ontwerpen-van- verandering); S. Gelinck e.a., Rekenen op herbestemming. Idee, aanpak en cijfers van $25+1$ gerealiseerde projecten, Rotterdam 2015; R. van Hees, S. Naldini en J. Roos, Durable past-sustainable future, Delft 2014; H. Ibelings en Diederendirrix Architects, Make it anew, Amsterdam 2018; M. Kuipers en W. de Jonge, Designing from heritage. Strategies for conservation and conversion, Delft 2017; M. Kuipers en W. Quist, Culturele draagkracht. Op zoek naar de tolerantie 
voor verandering bij gebouwd erfgoed, [Delft] 2013; P. Meurs, Heritage-based design, Delft 2016; P. Meurs, M. Steenhuis en J. de Groot, Reuse, redevelop and design. How the Dutch deal with Heritage, Rotterdam 2017; P. Nijhof e.a., Herbestemming industrieel erfgoed in Nederland, Zutphen 1994; B. Plevoets en K. van Cleempoel, Adaptive reuse of the built heritage. Concepts and cases of an emerging discipline, New York 2019; R. Roorda e.a., Vital architecture. Tools for durability = Vitale architectuur. Gereedschap voor levensduur, Rotterdam 2016; J. Saris, S. van Dommelen en T. Metze, Nieuwe ideeën voor oude gebouwen. Creatieve economie en stedelijke herontwikkeling, Rotterdam 2008; F. Scott, On altering architecture, Londen 2008; M. Steenhuis, P. Meurs en A. Kuijt, Herbestemming in Nederland. Nieuw gebruik van stad en land, Rotterdam 2011; H. Stevens, Hergebruik van oude gebouwen, Zutphen 1986; S. Stone, UnDoing buildings. Adaptive reuse and cultural memory, New York 2020; K. Vandenbroucke, Mag dit weg. Methodiek voor herbestemming, Rotterdam 2020; L. Wong, Adaptive reuse. Extending the lives of buildings, Bazel 2016.

2 E.M. Merrill en S. Gimarelos, 'From the Pantheon to the Anthropocene. Introducing resilience in architectural history', Architectural Histories 7 (2019) 1, doi. org/10.5334/ah.406; K. Trogal e.a., Architecture and resilience. Interdisciplinary dialogues, Londen 2019; M. Trachtenberg, Building-in-time. From Giotto to Alberti and modern oblivion, New Haven/ Londen 2010; J. van Ooijen, 'Resilient matters. The cathedral of Syracuse as an architectural palimpsest', Architectural Histories 7 (2019) 1, 26, doi. org/10.5334/ah.65

3 S. Brand, How buildings learn. What happens after they're built, New York 1994.

4 Zie hiervoor ook F. Schmidt, 'Moet opgeknapt worden. Gebouwen en hun aanpassingen', in: R. Stenvert en G. van Tussenbroek (red.), Het gebouw als bewijs. Het bouwhistorische verhaal achter erfgoed, Utrecht 2016, 145-208.

5 Merrill en Giamarelos 2019 (noot 2).

6 In D.M. Abramson, Obsolescence. An architectural history, Chicago 2016 laat de auteur zien dat de hoge omloopsnelheid en het afdanken van gebouwen in grote delen van de westerse wereld van de twintigste eeuw een simpel financieel model volgen.

7 R. Kousbroek e.a., Het paleis in de verbeelding. Het Paleis voor Volksvlijt 1860 1961, Amsterdam 1990; E. Wennekes, Het Paleis voor Volksvlijt (1864-1929). 'Edele uiting eener stoute gedachte!', Den Haag 1999; G. van Tussenbroek, IJzeren ambitie. Het Paleis voor Volksvlijt en de opkomst van de Nederlandse industrie, Amsterdam 2019.

$8 \mathrm{H}$. Heynen, 'Introduction to the theme "Petrified Memory"', The Journal of Architecture 4 (1999) 4, 331-332, 332.

9 H. Heynen, 'Petrifying memories: architecture and the construction of identity', The Journal of Architecture 4 (1999) 4, 369-39o, daarbij gebruik makend van M.C. Boyer, The city of collective memory. Its historical imagery and architectural entertainments, Cambridge 1994.

10 Heynen 1999 (noot 9).
11 Beleidsvisie 'Kiezen voor karakter, Visie erfgoed en ruimte'. Kamerstuk 15 mei 2011, 10. www.rijksoverheid.nl/documenten/kamerstukken/2011/o6/15/beleidsvisie-kiezen-voor-karakter-visieerfgoed-en-ruimte (20 juli 2020).

12 Zie noot 1.

13 Uitzondering hierop vormen Roorda 2016 (noot 1) en Kuipers en De Jonge 2017 (noot 1), voornamelijk voor de aan Frank Duffy ontleende 'shearing layers'.

14 Brand 1994 (noot 3), 210.

15 Brand 1994 (noot 3), 2. Elders (p. 53) waarschuwt Brand ook nog tegen 'overontworpen gebouwen', die nauwelijks aanpasbaar zijn.

16 Plevoets en Van Cleempoel 2019 (noot 1).

17 C. Norberg-Schulz, Genius loci. Towards a phenomenology of architecture, New York 1980.

18 Plevoets en Van Cleempoel 2019 (noot 1), 92-93; 126-131.

19 'This juxtaposing of different historical layers, however, did not compromise the authentic experience of the site. On the contrary, it enhances the richness and depth of its memory.' Plevoets en Van Cleempoel 2019 (noot 1), 92.

20 Plevoets en Van Cleempoel 2019 (noot 1), 93: 'We believe that for the discipline to move further, the future practice and theory of adaptive reuse should aim not just at respecting what is handed over from the past to the present but instead should actively search for the values and memory of the host space and try to establish a meaningful relationship between the present and the past through a sequence of tangible and intangible associations.'

PROF. DR. F. SCHMIDT is architectuurhistoricus, hoogleraar geschiedenis van de architectuur en de leefomgeving aan de Vrije Universiteit Amsterdam en ruimtelijk adviseur. Van 2002 tot 2008 en van 2012 tot medio 2020 was hij redacteur van het Bulletin KNOB.

\section{GENUINE ARCHITECTURE ON AUTHENTICITY AND ADAPTIVE REUSE}

\section{FREEK SCHMIDT}

This article is an appeal for independent, broad architectural-historical research prior to the redevelopment of buildings to protect their potential historical value and cultural significance. Authenticity is understood here as historicity and the article explores what it might signify in adaptive reuse, a growing sector in architectural design that is increasingly coming to be regarded as a separate discipline. In adaptive reuse strategies the building is viewed primarily as an architectural object that is to be given a 'new life'. But does that allow sufficient attention to be paid to the historicity of our living environment? How resilient and sustainable is a repurposed building? Stories that touch on the building, on testimonies in which place plays a role, on the intentions behind the design, and on changes to use: all these intangible aspects together determine the cultural value of the building in society, community and setting. That historicity, or genuineness and singularity, is crucial to the building's significance. What is needed above all is for the description of the historical and accumulated cultural value and significance of a building and place to be the starting point for redevelopment. Otherwise the spirit of the place disappears to be replaced only by novelty and entertainment, at the service of the contemporary consumer. 